\title{
СОВРЕМЕННЫЕ АСПЕКТЫ МИКРОБИОТЫ ДЕТЕЙ РАЗНЫХ В0ЗРАСТНЫХ ГРУПП
}

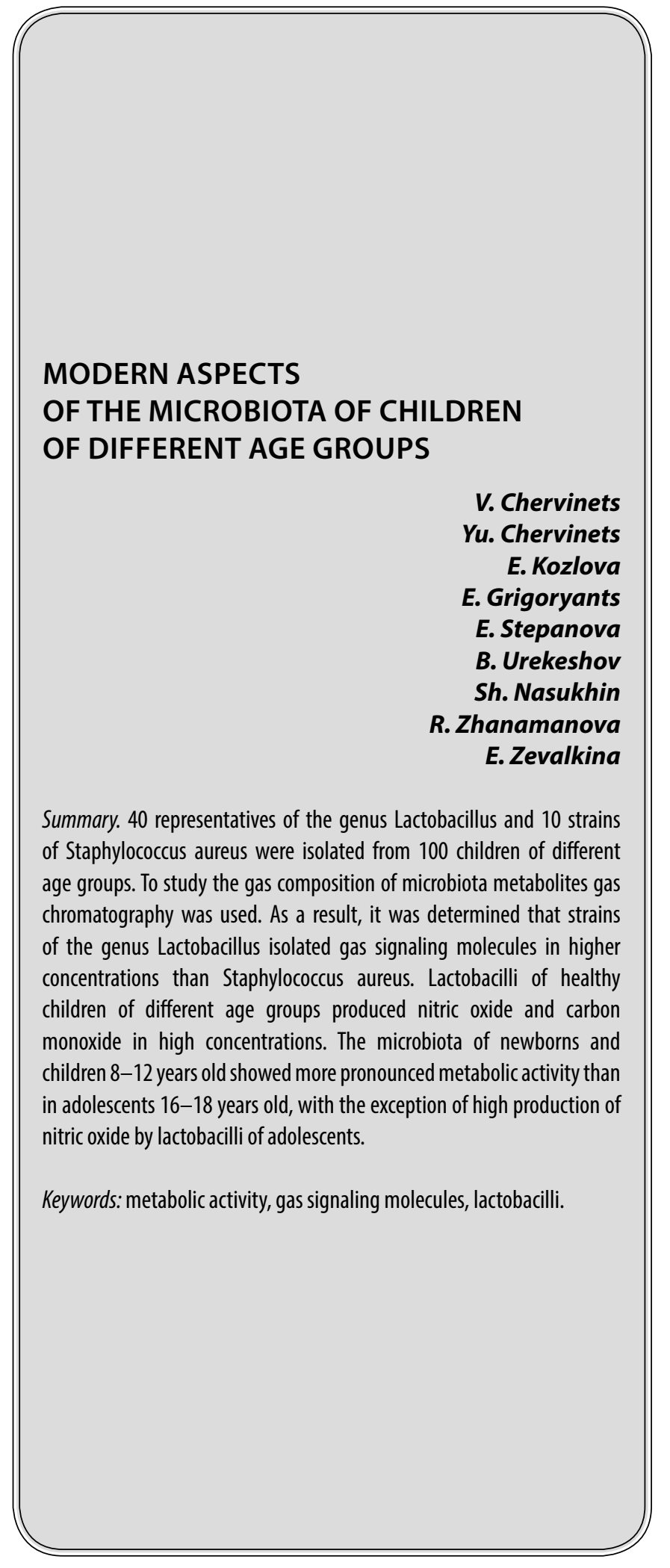

Червинец Вячеслав Михайлович Д.м.н., профессор, ФГБОУ ВО «Тверской Государственный медицинский университет» Минздрава России chervinets@mail.ru

Червинец Юлия Вячеславовна Д.м.н., профессор, ФГБОУВО «Тверской Государственный медицинский университет»

Минздрава России

julia_chervinec@mail.ru

Козлова Екатерина Андреевна

К.б.н., доцент, ФГБОУ ВО «Тверской Государственный медицинский университет» Минздрава России eabelyaeva1@mail.ru

Григорьяни Элина Олеговна Аспирант, ФГБОУ ВО «Тверской Государственный медицинский университет» Минздрава России lina.grigo@gmail.com

Степанова Эмма Валерьевна

Аспирант, ФГБОУ ВО «Тверской Государственный медицинский университет» Минздрава России s-emma@list.ru

Урекешов Бактыберген Садыкович К.м.н., дочент, ЗКМУ им. М. Оспанова, Казахстан, Актобе bakhty64@mail.ru

Насухин Шадыман Бактыгереевич К.м.н., ЗКМУ им. М. Оспанова, Казахстан, Актобе shada63@mail.ru

Жанаманова Раушан Нурболатовна Старший преподаватель, ЗКМУ им. М. Оспанова, Казахстан, Актобе roza.new.west@mail.ru

Зевалкина Елена Викторовна Преподаватель, ЗКМУ им. М. Оспанова, Казахстан, Актобе ezevalkina@list.ru

Аннотация. От 100 детей разных возрастных групп были выделены 40 представителей рода Lactobacillus и 10 штаммов Staphylococcus aureus. С помощью газовой хроматографии был изучен газовый состав метаболитов микробиоты. В результате определено, что штаммы рода Lactobacillus выделяли газовые сигнальные молекулы в больших концентрациях, чем Staphylococcus aureus. Лактобациллы здоровых детей разных возрастных групп в больших концентрациях выделяли оксид азота и окись углерода. Микробиота новорожденных и детей 8-12 лет показала более выраженную метаболическую активность, чем у подростков 16-18 лет, за исключением высокой продукции оксида азота лактобациллами подростков. 


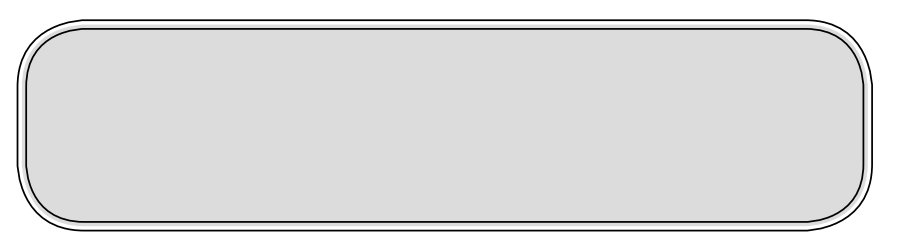

\section{Актуальность}

B современных условиях все большее внимание уделяется изучению микробиоты желудочно-кишечного тракта здорового человека, а также её влияния на поддержание и укрепление физиологических функций человека. В последние годы, на фоне ухудшения экологической обстановки, вопросы формирования и сохранения нормального микробиоценоза кишечника детей приобретают особую актуальность [1].

Для оценки микрофлоры желудочно-кишечного тракта важным аспектом является изучение метаболитов, которые выделяют микроорганизмы; среди них особая роль принадлежит сигнальным молекулам - простейшим по химической структуре газообразным соединениям эндотелиального и микробного происхождения (оксид азота-NO, оксид углерода-CO, сероводород- $\mathrm{H} 2 \mathrm{~S}$, водород - H2, метан- $\mathrm{CH} 4$, аммиак- $\mathrm{NH} 3$ и другие) [2]. В результате микробной ферментации в просвете кишечника накапливаются множество низкомолекулярных биологически активных соединений, включая летучие разнообразные газообразные продукты $[3,4]$. Суточный объем кишечных газов у взрослого человека может достигать 1200 мл. Среди них 20-90\% приходится на азот; 3,9-10\% - кислород; 20,9-50\% - водород; 7,2-10\% метан; 9-30\% - углекислый газ и 0,00028\% - сероводород. $\mathrm{H} 2$ и СН4 являются уникальными кишечными газами для организма человека, поскольку они формируются в организме только за счет микробной ферментации. Кроме того, в пищеварительном тракте могут накапливаться также аммиак, CO, NO и другие газы. Доказано, что многие из них способны проявлять разнообразные физиологические эффекты практически в каждом органе человека, а в определенных условиях участвовать и в патофизиологии тех или иных заболеваний [5].

\section{Цель настояшего исслеАования}

Оценить газовые сигнальные молекулы, выделенные от резидентной кишечной микробиоты здоровых детей разных возрастных групп.

\section{Материалы и метолы}

Материалом для исследования являлись фекалии здоровых детей разных возрастных групп. В качестве объектов исследовании выступали 36 новорожден-
Ключевые слова: метаболическая активность, газовые сигнальные молекулы, лактобациллы.

ных в возрасте до 1 месяца, 33 ребенка 8-12 лет и 31 подросток 16-18 лет. С использованием классических бактериологических методов исследования от новорожденных выделяли штаммы Staphylococcus aureus и представителей рода Lactobacillus, от детей в возрасте 8-12 лет и от подростков 16-18 лет выделяли представителей рода Lactobacillus. Идентификацию микроорганизмов проводили согласно биохимическому анализу с использованием тест-систем API ${ }^{\circledR}$ «Віо Merieux, Франция». Для определения наличия газовых сигнальных молекул в метаболитах микробиоты детей культуры микроорганизмов выращивали в 5 мл питательного бульона (MRS бульона для лактобацилл, МПБ бульона для стафилококков). Газовый состав метаболитов микробиоты проводился с помощью газовой хроматографии с применением газового хроматографа «Хроматэк-Кристалл 5000.2», оснащенного детектором по теплопроводности (ДТП), пламенно-ионизационным детектором (ПИД) и электронозахватным детектором (ЭЗД) [6].

\section{Результаты и обсужление}

От новорожденных было выделено 10 штаммов Staphylococcus aureus, 14 штаммов представителей рода Lactobacillus: L.fermentum - 8, L.paracasei - 3, L.rhamnosus -3;отдетейввозрасте8-12летвыделено 12 штаммов лактобацилл:L.paracasei-4,L.rhamnosus -4, L. curvatus-2,L.plantarum-2;отподростков 16-18лет изолировано 14 штаммов лактобацилл: L.fermentum 4, L.paracasei - 2, L.rhamnosus - 6, L. plantarum - 2 .

В результате настоящего исследования было выявлено, что лактобациллы, выделенные из кишечника новорожденных, вырабатывали $\mathrm{H}_{2} \mathrm{~S}$ (99 ppm) и СO (124,4 ppm) в 100 раз больше, чем золотистый стафилококк (0 и 3,1 ppm соответственно) (рис. 1). Продукция $\mathrm{H}_{2}$ и $\mathrm{CH}_{4}$ была очень низкая и практически одинаковая у стафилококков и лактобацилл (не более 2,7 ppm).

При сравнении продукции газовых молекул у детей разных возрастных групп выявлено, что лактобациллы, выделенные от новорожденных и детей 8-12 лет, выделяли практически одинаковую концентрацию $\mathrm{H}_{2} \mathrm{~S}(99$ и 94,2 ppm соответственно) и СО (124,4 и 182,9 ppm соответственно). Продукция $\mathrm{H}_{2}$ и $\mathrm{CH}_{4}$ была минимальной у обоих групп и не превышала 2 ррт. Лактобациллы, выделенные от подростков, показали минимальную кон- 


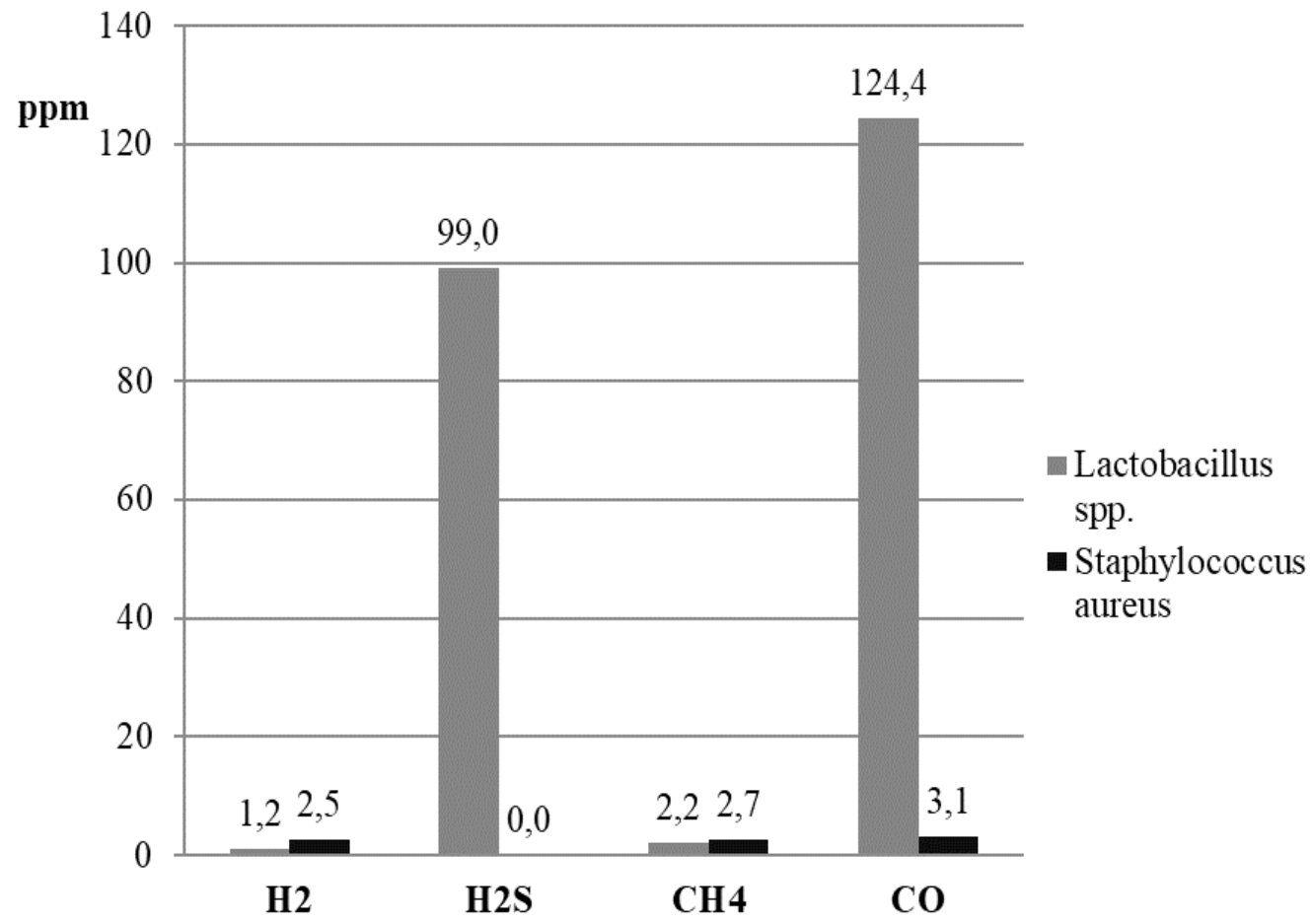

Рис. 1. Распределение газовых сигнальных молекул у микроорганизмов, выделенных у новорожденных.

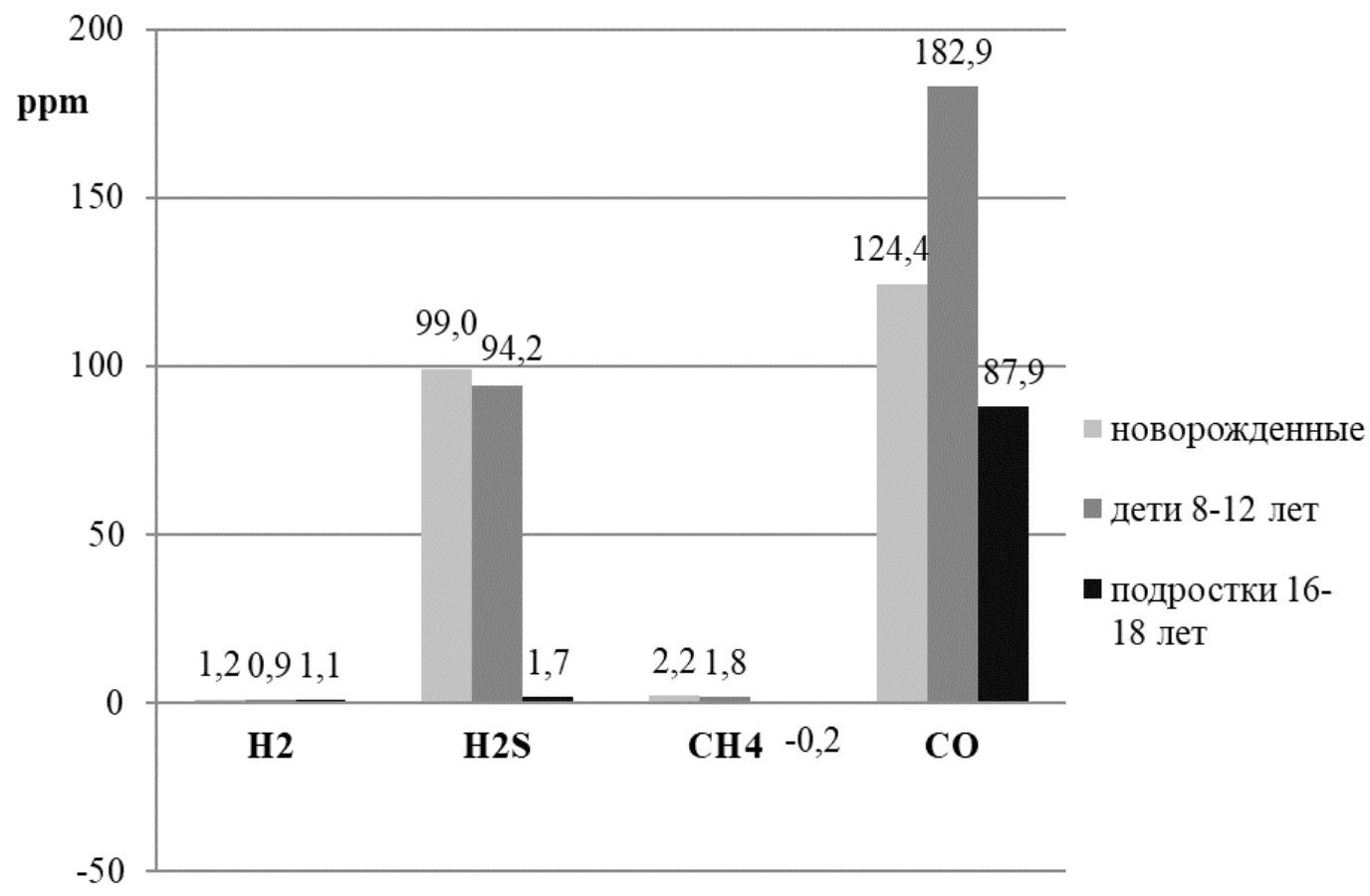

Рис. 2. Распределение газовых сигнальных молекул у лактобацилл в процессе их жизнедеятельности у детей разных возрастных групп. 
Таблица 1. Распределение атмосферных газов, выделяемых и поглощаемых микроорганизмами детей разных возрастных групп

\begin{tabular}{|l|l|l|l|l|}
$\begin{array}{l}\text { Поглощаемые } \\
\text { и выделяемые } \\
\text { атмосферные газы }\end{array}$ & \multicolumn{2}{|l|}{ Новорожденные } & $\begin{array}{l}\text { Дети 8-12 лет } \\
\text { Lactobacillus }\end{array}$ & $\begin{array}{l}\text { Подростки 16-18 лет } \\
\text { Lactobacillus }\end{array}$ \\
\hline & Staphylococcus aureus & Lactobacillus & & \\
\hline O2 (\%) & $-4,5$ & $-12,1$ & $-0,2$ & $-8,3$ \\
\hline N2 (\%) & 17,7 & $-30,7$ & 4,9 & $-31,9$ \\
\hline CO2 (ppm) & 15699,5 & 145263,8 & 26196,5 & 148658,9 \\
\hline
\end{tabular}

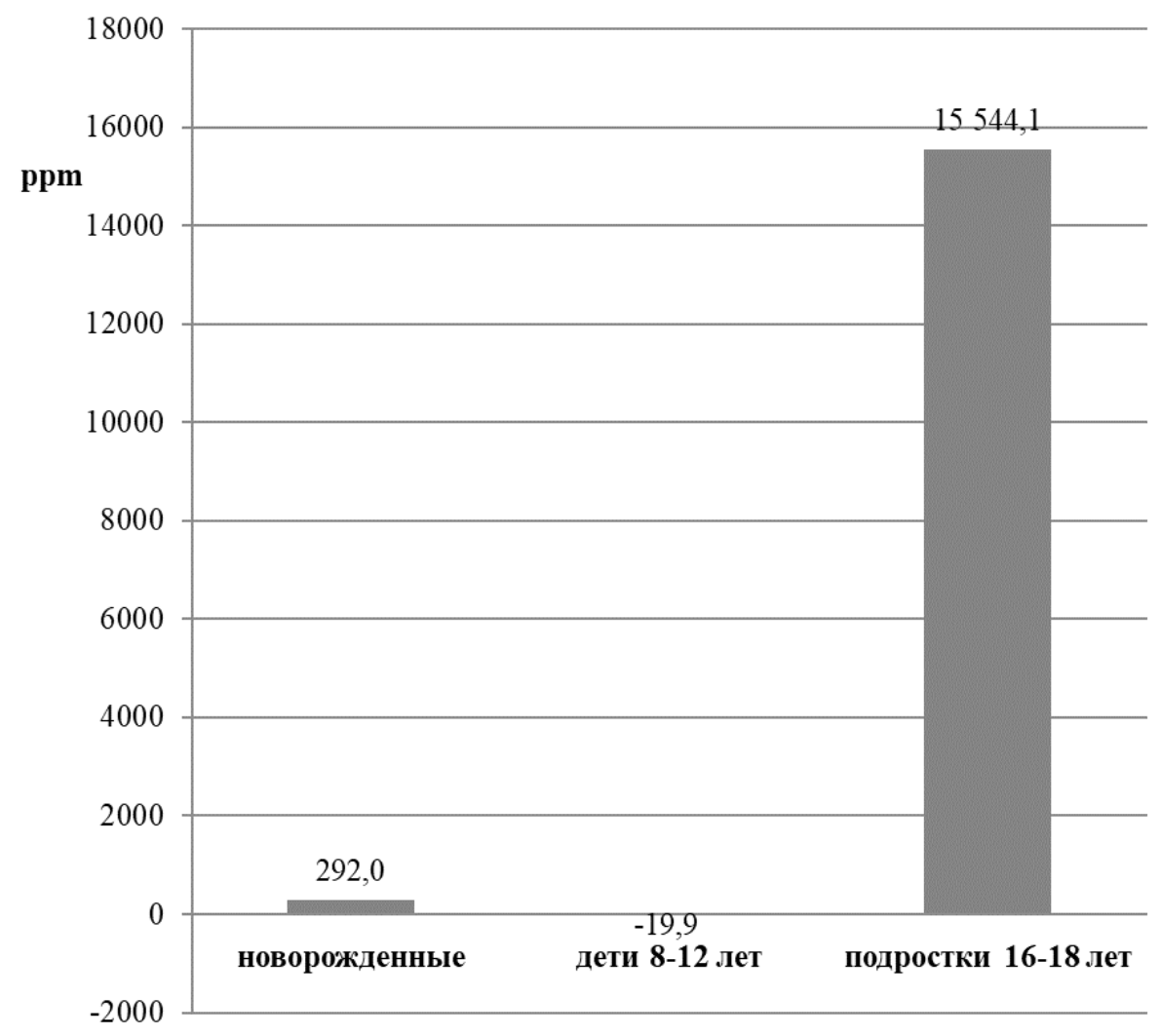

Рис. 3. Выделение NO у лактобацилл в процессе их жизнедеятельности у детей разных возрастных групп.

центрацию $\mathrm{H}_{2} \mathrm{~S}(1,7 \mathrm{ppm})$ и $\mathrm{CO}(87,9$ ppm) и полное отсутствие продукции $\mathrm{CH}_{4}$ (рис. 2).

Лактобациллы, выделенные от детей 8-12 лет, показали поглощение NO (-19,9 ppm), а от подростков 1618 лет - активное продуцирование NO (15544,1рpm), в 50 раз больше, чем у новорожденных (292 ppm) (рис. 3).

При изучении выделения и поглощения атмосферных газов микроорганизмами, показано, что лактобациллы новорожденных и подростков более активно поглощают кислород и азот и соответственно выделяют больше углекислого газа. Показатели атмосферных газов, выделенные от золотистого стафилококка новорожденных и от лактобацилл детей 8-12 лет, были практически одинаковыми и не отличались большими особенностями (табл. 1).

Известно, что сероводород является цитопротектором нервной и сердечно-сосудистой систем, а угарный газ в физиологических концентрациях оказывает кардиопротективный и противовоспалительный эффект [7]. По данным литературы многие кишечные микроорганизмы (в том числе бактерии рода Lactobacillus) образуют $\mathrm{H}_{2} \mathrm{~S}$ в нижних отделах пищеварительного тракта за счет продукции широкого спектра ферментов [8]. $\mathrm{H}_{2}$ является субстратом при образовании метана, сероводорода и ацетата и защищает клетки от окислительных 
повреждений [9]. $\mathrm{CH}_{4}$ - нервно-мышечный трансмиттер, способный снижать перистальтику кишечника [10]. В настоящее время установлено, что NO может выступать как нейротрансмиттер/нейромодулятор в мозге и в периферийной нервной системе [11].

\section{ВывОАы}

Таким образом, установлено, что бактерии рода Lactobacillus, как представители нормальной микрофлоры новорожденных, выделяли газовые сигнальные молекулы (NO, $\mathrm{H}_{2} \mathrm{~S}$ и $\mathrm{CO}$ ) в больших концентрациях, чем Staphylococcus aureus. Среди газовых сигнальных мо- лекул NO и CO выделялись в больших концентрациях лактобациллами здоровых детей разных возрастных групп. Микробиота новорожденных и детей 8-12 лет проявляет более выраженную метаболическую активность, чем у подростков 16-18 лет, за исключением высокой продукции NO лактобациллами подростков. Можно предположить, что за счет продукции лактобациллами газовых сигнальных молекул происходит регуляция многих физиологических процессов в клетках и тканях, в частности морфогенетических, метаболических, кардиопротективных, противовоспалительных, иммунорегулирующих, нейромодулирующих, репродуктивных.

\section{ЛИТЕРАТУРА}

1. Червинец В. М., Червинец Ю. В., Михайлова Е.С., и др. Микробиоценоз кишечника и иммунный статус у детей младшего школьного возраста // Клиническая лабораторная диагностика. 2013. № 1. С. 49-51.

2. Althaus M., Clauss W. G. Gasotransmitters: novel regulators of ion channels and transporters // Front Physiol. 2013. № 4. 27 p.

3. Belizario J. E., Napolitano M. Human microbiomes and their roles in dysbiosis, common diseases, and novel therapeutic approaches // Front. Microbiol. 2015. № 6 . $1050 \mathrm{p}$.

4. Shenderov B. A. Human Microbial Ecology and its Role in the Health // Metamorphoza. 2014. № 5. P. 72-80.

5. Червинец Ю. В., Червинец В. М., Миронов А. Ю. Симбиотические взаимоотношения лактобацилл и микроорганизмов желудочно-кишечного тракта: монография. Тверь: Центр Твер. гос. мед. ун-та, 2016. 214 с.

6. Способ диагностики газового состава метаболитов микробиоты человека: пат. 2683949 Российская Федерация, MПК G01N30/00 / В. М. Червинец, Ю. В. Червинец, Е. А. Беляева, Л. Ф. Червинец, А. В. Червинец, С. Н. Лебедев; ФГБОУ ВО Тверской ГмУ Минздрава России — № 2018112296; заявл. 05.04.18; 0публ. 03.04.2019.

7. Farrugia G., Szurszewski J. H. Carbon monoxide, hydrogen sulfide, and nitric oxide as signaling molecules in the gastrointestinal tract // Gastroenterology. 2014. № 147(2). P. 303-313.

8. Shatalin K., Shatalina E., Mironov A., et al. H2S: A universal defense against antibiotics in bacteria // Science. 2011. № 334. P. $986-990$.

9. Ishibashi T., Sato B., Rikitake M., et al. Consumption of water containing a high concentration of molecular hydrogen reduces oxidative stress and disease activity in patients with rheumatoid arthritis: an open-label pilot study // Medical Gas Research. 2012. № 2. 27 p.

10. Sahakian A. B., Jee S. R., Pimentel M. Methane and the gastrointestinal tract // Dig Dis Sci. 2010. № 55. P. 2135-2143.

11. Lundberg J. 0., Weitzberg E. Biology of nitrogen oxides in the gastrointestinsl tract // Gut. 2013. № 62(4). P 619-629.

(c) Червинец Вячеслав Михайлович ( chervinets@mail.ru ), Червинец Юлия Вячеславовна ( julia_chervinec@mail.ru ), Козлова Екатерина Андреевна ( eabelyaeva1@mail.ru ), Григорьянц Элина Олеговна ( lina.grigo@gmail.com ), Степанова Эмма Валерьевна ( s-emma@list.ru ), Урекешов Бактыберген Садыкович ( bakhty64@mail.ru ), Насухин Шадыман Бактыгереевич ( shada63@mail.ru ),Жанаманова Раушан Нурболатовна ( roza.new.west@mail.ru ), Зевалкина Елена Викторовна ( ezevalkina@list.ru).

Журнал «Современная наука: актуальные проблемы теории и практики» 